POLIIICAL ECONOMY RESEARCH INSTIIUTIE

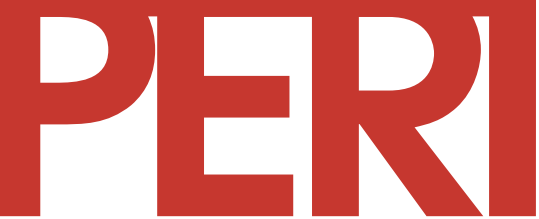

University of Massachusetts Amherst

\title{
A Future for Small Farms? \\ Biodiversity and Sustainable Agriculture
}

\author{
James K. Boyce
}

2004

Gordon Hall

418 N. Pleasant St, Suite A Amherst, MA, 01002-1735 Telephone: (413) 545-6355 Facsimile: (413) 577-0261 Email:peri@peri.umass.edu Website:

http://www.umass.edu/peri/

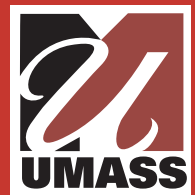




\section{A Future for Small Farms? Biodiversity and Sustainable Agriculture}

James K. Boyce *

July 2004

\footnotetext{
* Revised version of a paper prepared for the Conference on Egalitarian Development in the Era of Globalization, in Honor of Professor Keith Griffin, held at the Political Economy Research Institute, University of Massachusetts, Amherst, MA, April 2004. I am grateful to Liz Stanton and Sue Holmberg for research assistance, and to Garrison Wilkes and conference participants for comments. This paper will appear in a forthcoming conference volume edited by Robert Pollin, Steven Cullenberg, Prasanta Pattanaik, and the author.
} 


\begin{abstract}
Small farms play a crucial role in conserving the agricultural biodiversity that underpins longterm food security worldwide. Particularly in centers of crop genetic diversity - such as Mesoamerica in the case of maize (corn) and the Andean region in the case of potatoes - small farmers are the 'keystone species' in agricultural ecosystems of great value to humankind. Today, however, a formidable nexus of market forces and political forces threatens both small farmers and the biodiversity they sustain. Countervailing public policies are urgently needed. These should include the removal of existing policy biases against small farmers; social recognition of the contribution of in situ conservation to human well-being; development of markets for 'traditional' varieties of crops and livestock; the provision of local public goods in areas where farmers cultivate diversity; payments for the environmental service of on-farm conservation; and support for part-time farming as an element of diversified household livelihood strategies.
\end{abstract}

\title{
Introduction
}

The small farmer is today an endangered species. In the industrialized countries of the global North, the number of farmers has been dwindling for generations. In the United States, for example, the total number of farms fell from 6.8 million in 1935 to fewer than 2 million today (Stam and Dixon, 2004). Referring to trends in Europe, where the farming population is now declining by three percent annually, a recent The New York Times editorial derides the idea that 'every village that was inhabited in Charlemagne's day must be sustained,' and declares that 'more consolidation, in the form of larger-scale farming and an abandonment of absurdly inefficient production, is inevitable.'

In the developing countries of the global South, governments and international agencies alike appear to be intent on following the same path. Fifty years after the publication of Sir Arthur Lewis's (1954) dual-economy model, in which economic development was identified with the transfer of labor from the 'subsistence' agricultural sector to the 'capitalist' industrial sector, the assumption that small farms are destined for the dustbin of history remains conventional wisdom. 'Those indios,' a Guatemalan official told me a few years ago, referring to the country's indigenous majority, 'as long as they grow maize just like their grandparents, they'll be poor just like their grandparents.' 2

Rather than simply letting nature take its ostensible course, governments often seek to speed it along, promoting agricultural 'modernization' by means of subsidies and other policies that favor large-scale farming, purchases of farm machinery and chemical inputs, and more uniformity in the choice of crops and varieties. In a sense, these policies aim to subsume agriculture itself, and not only its erstwhile labor force, into the industrial economy. Even if the demise of the small farm were not a foregone conclusion, these policies could make it a self-fulfilling prophecy. 
In the face of these trends, an intrepid band of economists has rallied to the defense of small farms on grounds of both equity and efficiency. Prominent among them is Keith Griffin, who warned in his classic study, The Political Economy of Agrarian Change (1979, p. xxii) against policies that could 'lead to the creation of an inefficient and capital intensive agriculture which is incapable of producing an adequate livelihood for the mass of the rural population.' Over the years, Griffin has held fast to this position. In a recent article co-authored with his colleagues Azizur Rahman Khan and Amy Ickowitz (2002, p. 320), he insists that 'family farms use resources efficiently and can be just as dynamic as large farms.'

Among economists, the arguments in favor of small farms have gained ground in the last few decades. The efficiency advantages of small farms - rooted in their labor intensity - have won increasing recognition, even in bastions of the development establishment such as the World Bank. ${ }^{3}$ Yet policies on the ground have been slow to change. As Griffin (1979, p. 84) observed, the policy mix that favors larger farms is primarily attributable not to ignorance, but rather to the political influence of large landowners: 'Governments may claim to rule in the "national interest”,' he wrote, 'but in reality they act in behalf of their supporters.' A shift toward prosmall farm policies is unlikely to be brought about by small farmers acting alone.

This essay offers a further argument on behalf of small farms, based on their role in providing a crucial public good: the conservation of agricultural biodiversity. ${ }^{4}$ From the highland maize plots of southern Mexico and Guatemala to the rice paddies of eastern India and Bangladesh, small farmers across the world sustain the crop genetic diversity that underpins humankind's long-term food security. Many of those who provide this public good are desperately poor, and their continued ability and willingness to cultivate diversity can no longer be taken for granted. Policies to reward small farmers for their contributions to global food security would help to ensure both their future and our own.

Of course, this does not mean that all small farms - or, in the reducto absurdum line of the Times, 'every village inhabited in Charlemagne's day,' should endure forever. Nor does it mean that we need to create living museums where the agricultural landscape is frozen in time. On the contrary, a hallmark of 'traditional' agriculture is precisely its dynamism: in the farmers' fields, the process that Charles Darwin termed 'artificial selection' - natural selection guided by human hands - yields a constant stream of new varieties, adapted to changing needs and changing environmental circumstances. ${ }^{5}$ But to say that not all small farms, or all crop varieties, can or should survive is not to say that a world of large, monocultural farms is desirable or feasible as the endpoint of agricultural history. A productive and resilient world agriculture requires a diverse mix of crop varieties, agricultural techniques, and farming systems. In this mix, there is a future for small farms.

\section{Humans as a Keystone Species}

As early as the 1500s, Spanish settlers began to arrive in the valley of the upper Rio Grande, in what is now the southwestern United States. To irrigate the semi-arid lands they found, the settlers constructed acequias, earthen channels that divert river water and carry it to valley slopes downstream. These gravity-fed irrigation systems transformed the landscape into a diverse 
agroecosystem that includes wetlands, fields and orchards with unique varieties of beans and fruit trees, riparian corridors for wildlife movement, and fertile soils built by generations of careful land stewardship.

Anthropologist Devon Peña (2003, p. 169) describes humans as the 'keystone species' of this acequia landscape mosaic - 'a species so central to the health of the ecosystem that without it many other species could not survive.' The idea that humans can act as a keystone species playing a role in nature akin to that of beavers in the Canadian forests, or corals in ocean reefs marks a profound departure from the image, widespread among environmentalists, of human beings as alien intruders whose 'ecological footprint' invariably tramples upon the fragile shoots of the natural world. Instead, it evokes a more balanced assessment of the relationship between humans and nature, one in which humans can have positive impacts, as well as negative ones, on the richness and diversity of life.

Another striking illustration of the potential for positive human impacts has come to light in recent years in South America. About $10 \%$ of the Amazonian region - with an area roughly the size of France - is covered by deep, dark soil known locally as terra preta do indio (dark earth of the Indians) that is prized for its long-lasting fertility. Terra preta is a remarkable exception to the general rule that tropical rainforest soils are poor in nutrients, and hence subject to rapid degradation once the forest cover is removed. Soil scientists have concluded that terra preta was created by the indigenous people who practiced 'slash-and-char' agroforestry in the region for two millennia. ${ }^{6}$ An astonishing feature of terra preta is its capacity to regenerate itself: 'In a process reminiscent of dropping microorganism-rich starter into plain dough to create sourdough bread,' scientists hypothesize that 'Amazonian peoples inoculated bad soil with a transforming bacterial charge’ (Mann, 2000b, p. 52).

More generally, it is not an exaggeration to say that most people today depend for their very survival on the fruits of past human interactions with nature. If we pause to give thanks before we eat a meal, our gratitude should extend to predecessors who first domesticated plants and animals, and over the millennia created the many thousands of varieties of these species that underpin the world's agriculture. Crops such as wheat, rice, maize, potatoes, and cotton did not appear on Earth by some happy circumstance. These and the other species on which we rely for our food and fiber arose in a process of 'coevolution' with human cultures. Beginning some ten thousand years ago, the inhabitants of Asia Minor domesticated wheat and barley, grains whose seeds have the key property of not 'shattering' and falling to the ground as they ripen. Their counterparts in Asia gave us rice, a versatile plant whose roots can survive in continuously flooded fields. In the Andes, early Americans gave us the potato. In Mesoamerica, perhaps most remarkably of all, the forbearers of today's Mayan campesinos evolved maize from its wild relative, teosinte. ${ }^{7}$ Were humans to vanish from the planet, these species would vanish in short order, too.

To term these developments 'beneficial' is, of course, to make a normative judgment. From a 'deep ecology' perspective in which humans are just another species, whose survival is of no greater consequence than that of any other, the judgment that the acequia ecosystem, or terra preta, or food crops can be termed positive achievements might be questioned. If, however, our value system embraces a concern for the biosphere's capacity to sustain human well-being, then 
I think these deserve to be called improvements in the state of nature. To be sure, there are plenty of counterexamples where human activities have had negative environmental impacts. But positive impacts are part of our story, too.

\section{Small Farmers: Cultivators of Diversity}

Today, perhaps the single most important examples of humans acting as a keystone species are the agroecosystems that maintain the world's crop genetic diversity. Most of the 'keystone' people are small farmers. In part, this is because agricultural biodiversity is concentrated in regions of the world where small farms still predominate. In part, too, it is because small farmers have comparative advantages in the cultivation of diversity.

\section{Centers of agricultural biodiversity}

The centers of origin of the world's crops are concentrated in a few places, known as 'Vavilov centers' after the great Russian botanist of the early $20^{\text {th }}$ century, Nikolai Vavilov. Most of the Vavilov centers are in the developing countries of the global South (see Figure 1). Vavilov hypothesized that the ancient centers of crop origin tend to be the modern centers of crop diversity, a suggestion that, by and large, has stood the test of time. The logic behind this correlation is straightforward: crops evolve as farmers select seed for replanting from individual

Figure 1: Centers of Origin of Crops

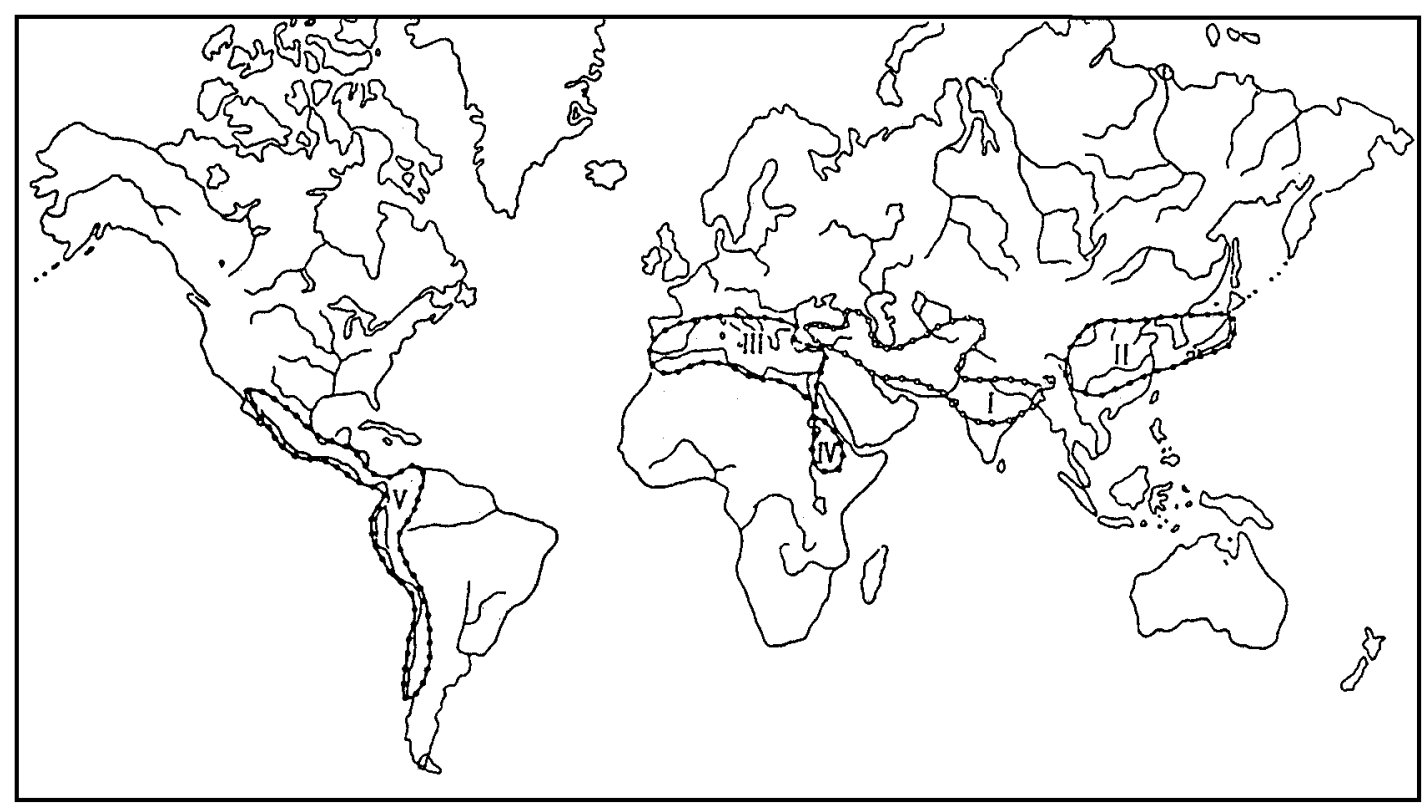

Key: I. Southwestern Asia; II. Eastern Asia; III. the Mediterranean area; IV. Abyssinia and Egypt; V. mountainous areas of Mexico, Central America, and South America. Source: Vavilov (1992 [1926], p. 127). 
plants that perform best in the face of local variations in soils, rainfall, altitude, pest populations, and so on. Diversity tends to be greatest where this process has had the longest time to unfold. In the Bengal delta, for example, where 'a few inches difference in elevation in relation to expected flooding depth and duration can cause farmers to plant different rice varieties,' some 10,000 different varieties of rice were being grown in the 1970s (Brammer, 1980, p. 25).

Darwin described this process in the opening chapter of The Origin of Species: 'The key is man's power of accumulative selection: nature gives successive variations; man adds them up in certain directions useful to him.' One of Darwin's examples was the strawberry, a fruit that was growing in popularity at the time: 'Gardeners picked out individual plants with slightly larger, earlier, or better fruit, and raised seedlings from them, and again picked out the best seedlings and bred from them.' In this way, Darwin explained, 'those many admirable varieties of the strawberry were raised which have appeared during the last half-century’ (Darwin, 1952 [1859], pp. 18, 23).

As Vavilov documented, crop genetic diversity is distributed very unevenly across the globe. The available data on this point are remarkably sparse, but a rough indicator is the sources of seed samples that are stored in the world's largest 'gene banks', ex situ (off-site) collections maintained for possible future use by scientists and plant breeders. In the case of maize, for example, Mexico accounted for 4220 of the maize accessions held at the International Maize and Wheat Improvement Center (known by its Spanish acronym, CIMMYT) in the mid-1990s, and Guatemala for another 590; by contrast, the United States, with more than three times the maize acreage of Mexico and Guatemala combined, accounted for only 43 samples (Boyce, 1996). Mexican farmers today are believed to grow roughly 5,000 different varieties of maize, whereas in the United States - where corn is sown on roughly 70 million acres - more than $70 \%$ of the acreage is planted with varieties 'based on no more than half a dozen inbred lines' (Goodman 1995, p. 200). ${ }^{8}$

\section{Comparative advantages of small farmers in cultivating diversity}

Around the world, it is generally small farms - especially those in the Vavilov centers - that practice high-diversity agriculture. Not only do individual small farmers often choose to cultivate several varieties of the same crop, but also, and probably more importantly, different farmers in a given locality often cultivate different varieties. Large farms, in contrast, are more likely to sow a single variety over a wide area. This inverse relationship between farm size and varietal diversity has several explanations.

First, high-diversity farming is generally more labor-intensive than low-diversity farming. It takes more time and effort to cultivate varieties with different sowing dates, harvest times, and other requirements than to practice varietal monoculture. Considerable labor also is needed to maintain the physical infrastructure - such as watercourses and terraces - that often supports high-diversity agriculture. As we know from the many studies of the relationship between farm size and labor use, smaller farms have a comparative advantage in labor-intensive operations. This is because they rely more on family labor, the 'real cost' of which is lower than the wage of hired labor, and because insofar as they do use hired laborers, small farmers have fewer supervision problems (not only is supervision easier on small farms, but also the need for 
supervision may be less by virtue of the narrower social distance between employer and employee). ${ }^{9}$

Second, high-diversity agriculture depends on the farmers' knowledge of different crop varieties and their relationships to microhabitat variations. Small farmers are the repositories of this knowledge. Without them, it would be harder not only to sustain agricultural biodiversity, but also to know the attributes of the varieties that are being sustained. Indigenous cultures often are particularly rich in this knowledge. For example, the Mixe language, spoken by maize farmers in southern Oaxaca, Mexico, has words for 'a greater and richer number of stages of plant development (germination, flowering, leaf and whorl development, appearance of black color at base of kernels, etc.) than those existing in conventional scientific literature. ${ }^{10}$

Third, small farmers often predominate in 'marginal' agricultural environments where the spread of 'modern' varieties has been held in check by unfavorable growing conditions. Hilly terrain, as in the highlands of southern Mexico and Guatemala, is less suitable for monoculture and mechanization; similarly, in deeply flooded parts of the Bengal delta, the short-statured 'highyielding' (that is, highly fertilizer-responsive) varieties cannot be grown. Such lands are relatively unattractive targets for appropriation and concentration by landowning elites. At the same time, they often have exceptionally high degrees of microenvironmental variation, which favors varietal diversification. In a single village in Oaxaca, for example, researchers Raúl and Luis García-Barrios (1990) found that the campesinos distinguished among 17 different environments in which they grew 26 distinct varieties of maize. Similarly, Maori weavers in New Zealand recognize more than 80 distinct varieties of flax (Shand, 1997, p. 11, citing Heywood, 1995).

As already noted, 'traditional' agriculture is by no means static. The artificial selection process that created crop genetic diversity continues unabated in farmers' fields, leading botanists to refer to these fields as 'evolutionary gardens. ${ }^{, 11}$ In this process, the line between 'traditional' and 'modern' agriculture often becomes blurred, as small farmers adopt and adapt new varieties released by professional public-sector and private-sector plant breeders. ${ }^{12}$ As Stephen Brush (1995), among others, has observed, traditional varieties can co-exist with modern varieties. Moreover, even after the introduction of new varieties, the processes of cross-pollination, mutation, and artificial selection continue to give rise to successive generations adapted to local conditions. In Bangladesh, for example, by selecting seed from the tallest plants in fields of short-statured 'green-revolution' rice varieties, farmers developed in the space of a few years new varieties that are suitable for more deeply flooded fields. ${ }^{13}$ Given the dynamic character of traditional agriculture, the 'traditional-modern' dichotomy is better described as a contrast between high-diversity and low-diversity agricultural ecosystems.

\section{Diversity and Efficiency}

There is a fundamental tension between the 'efficiency' promoted by markets and a broader notion of efficiency, founded on long-term human well-being, that (i) encompasses externalities, both positive and negative, and (ii) puts the welfare of future generations on a par with presentday welfare, rather than discounting it towards zero. The logic of the market puts little value on 
crop genetic diversity. Instead it dictates that in any given time and place all farmers should grow the same 'optimal' variety, tempered only by local differences in soils, climate, and so on. Apart from some variations in response to local differences, the market puts no value on diversity per se: less profitable varieties are driven out by more profitable varieties. Yet in the long run, diversity is crucial if agriculture is to be resilient. The farmers who maintain diversity thus provide a positive externality, a social benefit that the market fails to reward.

\section{The varietal relay race}

The basic problem with low-diversity agriculture is that time and nature do not stand still. Among the insects and plant pathogens that thrive in the green blanket of corn that covers the midsection of the United States every summer, the Darwinian process of survival of the fittest proceeds, favoring the evolution of new strains of pests that are particularly well-adapted to the handful of corn varieties being grown on millions of acres of farmland. State and federal agricultural officials monitor the fields for outbreaks of new insect and plant disease threats. Plant breeders respond by screening their breeding lines for varieties with resistance to these new strains, and incorporating this resistance into the next generation of cultivars (cultivated varieties). The average commercial lifespan of a newly released corn variety in the U.S. is only seven years, after which it is rendered obsolete by the emergence of new strains of insects or plant diseases (Duvick, 1984, p. 164). Surveys of a number of major crops undertaken for the U.K. Department of the Environment in the mid-1990s found that 'the viability of any given product is only about five years, with pests and disease being the primary factors for the obsolescence' (Swanson and Luxmoore, 1997, p. 98).

The same process occurs wherever agricultural 'modernization' results in a high degree of varietal uniformity. In the case of Asian rice agriculture, for example, 'under the intensive cultivation practices, insect pests of short life span and heterogeneous population structure, such as the brown planthopper, can quickly adapt their genetic population structure in response to the resistance gene in the most widely grown cultivar' (Chang 1995, p. 154). Rice breeders at the International Rice Research Institute (IRRI) in the Philippines and at national agricultural research institutions again must respond by releasing new varieties with resistance to the new threats.

Monocultural optimization not only creates an environment that favors evolution of virulent new pests and diseases. It also creates one in which, if and when such organisms emerge, they can trigger widespread crop failures. This genetic vulnerability - arising from the eggs-in-one-basket syndrome - is the soft underbelly of low-diversity agriculture. To cope with this vulnerability, plant breeders rely on 'diversity through time,' breeding and releasing new crop varieties (Duvick, 1984; Duvick et al., 2004). In a sense, then, 'low-diversity' agriculture is a misnomer: the viability of modern agriculture rests on the substitution of time-series variation for crosssectional variation.

The stakes in this 'varietal relay race' are high, as was demonstrated in the United States in 1970, when the southern corn leaf blight destroyed one billion bushels of maize, including as much as half the harvest in some southern states. The epidemic was caused by a new strain of a fungus, 
Bipolaris maydis, which was virulent on plants with a genetic makeup shared by $85 \%$ of the maize grown in the US at the time. Plant breeders were able to respond in the following year by incorporating genetic resistance they found in some maize varieties grown in Africa. Scientists were 'shaken by how close the system had come to disaster,' Mann (2004, p. 7) reports; 'they had been lucky that the problem was quickly contained, and luckier still that the African maize had not been supplanted by vulnerable modern hybrids.'

As the corn leaf blight example illustrates, the raw material for the varietal relay race ultimately comes from the crop genetic diversity bequeathed to us by previous generations and today sustained by small farmers around the world. In other words, the long-run sustainability of lowdiversity agriculture rests on a continuing flow of biological inputs from the high-diversity agriculture. The irony is that by virtue of its superior short-run 'efficiency,' modern agriculture is undermining the economic viability of traditional agriculture: the small farmers who cultivate diversity face increasing competition from the 'green revolution' at home, and from cheap agricultural imports from the industrialized countries. In the quest for high productivity, botanist Garrison Wilkes explains, we have 'built our roof with stones from the foundation.' ${ }^{14}$

\section{The need for in situ diversity}

The seed collections held at public-sector agricultural research institutions around the world are storehouses of crop genetic diversity. When dried and kept under controlled temperature and humidity conditions, the seeds can remain viable for a number of years (often around three decades); if then planted, with care to prevent cross-pollination, the seed can be replicated and stored again. These ex situ 'gene banks' - including the wheat and maize collections at CIMMYT in Mexico; the rice collection at IRRI in the Philippines; the potato collection at the International Potato Center in Peru; and the US Department of Agriculture's National Seed Storage Laboratory (NSSL) in Fort Collins, Colorado - are public goods of immense value to humankind. They do not represent an adequate substitute for in situ (in-the-field) diversity, however, for several reasons.

First, the gene banks are not completely secure. Accidents, wars, and chronic underfunding all make the survival of the stored seeds precarious. The world's largest ex situ collection of crop varieties is - or was - at the Vavilov Institute in what for a time was called Leningrad and now once again is called St. Petersburg. In their book, Shattering, Cary Fowler and Pat Mooney recount the drama that unfolded at the Vavilov Institute during the siege of Leningrad in World War II. With food supplies cut off by the German army, people ate dogs, cats, and even grass in an effort to survive. In the end, more than half a million of the city's residents starved to death. The dead included staff members of the Institute, who took extraordinary measures to safeguard seeds that they could have eaten to prolong their own lives. 'When all the world is in the flames of war,' a survivor recalls the staff telling each other, 'we will keep this collection for the future of all people’ (Fowler and Mooney, 1990, pp. 221-2).

Today, plant breeders believe that most of the seeds held at the Vavilov Institute are no longer viable - in other words, they are dead. The reason is the inadequate maintenance and replication of the collection in the years before and since the breakup of the Soviet Union. A similar fate 
may have befallen what was once the world's second largest maize collection (after that of the Vavilov Institute) in Belgrade, the capital of the former Yugoslavia (Plucknett at al., 1987, p. 120). Even in relatively prosperous and stable nations, like the United States, accidents and funding shortages make the ex situ collections less than perfectly secure. ${ }^{15}$

A second reason why ex situ collections cannot adequately replace in situ diversity is that, at best, gene banks conserve only the existing stock of crop genetic diversity. They cannot mimic the ongoing flow of new varieties that happens in the farmer's field under the pressures of natural and artificial selection. 'A main object of in situ conservation,' Brookfield (2001, p. 248) concludes, 'should be to enhance the processes that create genetic diversity, not to protect any actual body of genetic material.' It would require great hubris to imagine that we can safely terminate the coevolutionary process that small farmers have carried forward for thousands of years, and henceforth delegate all crop breeding to professional scientists mining the existing stock of diversity held in seed collections.

Finally, there is a world of difference between having a seed 'in the bank' and knowing what you have. Many genetic attributes can be observed only by growing plants in the microhabitats from which they come. The fact that a certain maize variety can withstand intermittent drought at fourweek intervals, for example, or that is resistant to a particular strain of fungus, is not apparent unless it is grown in circumstances that reveal these qualities. Relying on artificial growth chambers to obtain this information would be very expensive. In effect, knowledge of the attributes of diverse varieties - knowledge that resides in the farmers who grow them - is a vital component of diversity itself. As Garrison Wilkes puts it, 'sun, soil, seeds, and smarts' are the 'four S's of farming., 16

None of the foregoing is meant to disparage the importance of ex situ collections or minimize their need for adequate financial support. Ex situ collections provide a conduit for plant breeders to access diversity, and they provide insurance against losses of diversity in the field. For example, Cambodian rice varieties that were lost during the war and the disruption of the Khmer Rouge period subsequently were reintroduced using seeds that had been stored at IRRI. ${ }^{17}$ But the insecurity of ex situ collections, the importance of continued evolution in the field, and the need for information about varietal attributes all mean that the world needs in situ diversity, too. In situ and ex situ diversity are complements, not substitutes.

\section{Small Farmers as an Endangered Species}

From the highlands of Mesoamerica to the river deltas of south Asia, the ability of small farmers to sustain agricultural biodiversity is threatened by their lack of livelihood security. For example, in Mexico - where there is a striking geographical correlation between maize diversity and the prevalence of infant malnutrition (see Figure 2) - outmigration from rural areas is highest 'where corn production is carried out in small plots, with local varieties, and where poverty is pervasive' (Nadal, 2000, p. 8). ${ }^{18}$ In the last few years, rural outmigration has been limited by Mexico’s economic crisis and the lack of urban employment opportunities, but this could change quickly if the economy improves (Ackerman et al., 2003). Poverty cannot provide a durable basis for conserving in situ diversity. 
Figure 2: Maize Diversity and Infant Malnutrition in Mexico
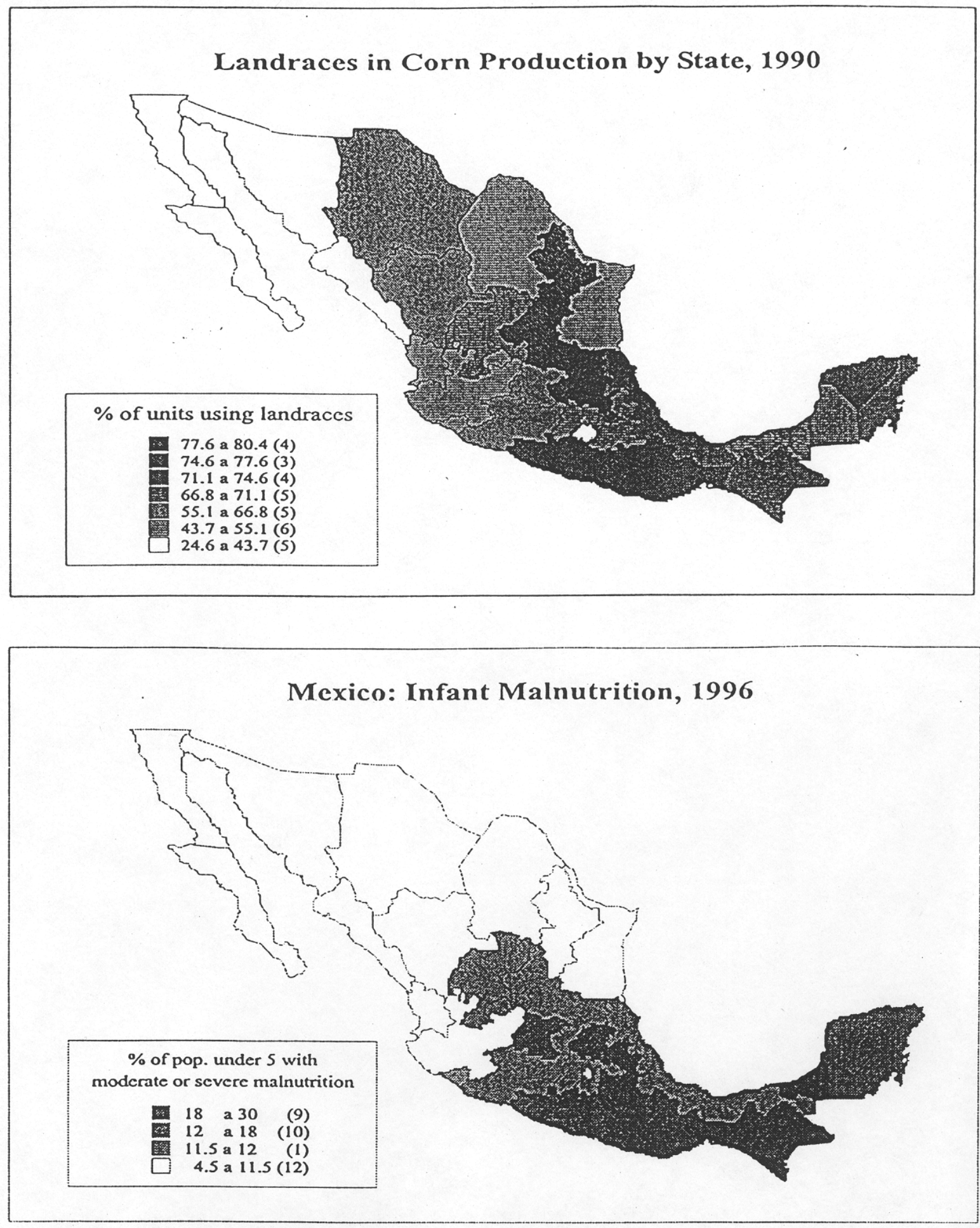

Source: Nadal (2000, pp. 50, 90). 
Outmigration of farmers is propelled by 'pull' factors and 'push' factors. On the 'pull' side are the lures of urban employment, the 'bright lights' of the city, and better access to education and health services. Yet the fate of displaced small farmers in urban areas is often grim: the work that awaits them is often low-paid, insecure, and hazardous; their housing is precarious and inadequate; and they no longer have access to land for subsistence production. To understand what makes these urban options seem attractive in comparison to farming, we must look at the 'push' side of the migration equation. Two factors that help to explain why small farmers find it increasingly difficult to earn a living on the land are agricultural 'modernization' and international agricultural trade. On a level playing field, neither of these necessarily would be inimical to the small farmer. All too often, however, both are played out on a terrain that is tilted against small farmers.

\section{Agricultural 'modernization'}

Agricultural 'modernization' is often spearheaded by the introduction and diffusion of highly fertilizer-responsive crop varieties, a process epitomized by the 'green revolution' in rice and wheat agriculture that was launched in Asia and Latin America in the 1960s. In principle, this technology was divisible and labor-intensive, and thus well-suited to small farms. In practice, as Keith Griffin documented in The Political Economy of Agrarian Change, large landowners often reaped the lion's share of the benefits. Small farmers lost out not only in relative terms, but also absolutely insofar as large farmers were able to expand operations at their expense.

This polarization occurred for several reasons. First, the new varieties were best suited to regions well-endowed with water-control infrastructure, such as the states of Punjab and Haryana in India, leaving producers in poorer regions to face adverse effects from falling output prices and/or rising input prices. Second, within regions, large farmers had preferential access to irrigation hardware and subsidized credit, positioning them to reap windfall gains as 'early adopters' of the new technology. Third, large farmers used their political power, bolstered by these income gains, to extract further state support, including subsidies for farm machinery that helped to offset the labor-cost advantages of small farmers. Fourth, in settings where land often changes hands through transactions that involve some degree of 'extra-economic' coercion, the green revolution enhanced both the incentive for large landowners to wrest control of lands from smaller farmers, and their power to do so. ${ }^{19}$

Insofar as agricultural modernization triggers displacement of small farmers, it undermines the social basis for agricultural biodiversity. To be sure, new technologies can lead to genetic erosion on small farms, independently of changes in the agrarian structure, if small farmers themselves decide to replace numerous local varieties with fewer new ones. ${ }^{20}$ As noted above, however, it is possible for traditional crop varieties and farming practices to co-exist with new ones. Indeed one can imagine situations where the introduction of new varieties enhances diversity rather than diminishing it. ${ }^{21}$ The impact of ‘modernization' on agricultural biodiversity hinges, in no small measure, on how it affects the livelihood security of small farmers. As the small farmer goes, so goes diversity. 
International agricultural trade

A second 'push' factor arises from the growth of international agricultural trade. Small farmers in the developing countries of the global South now face intensifying competition from cheap grain imported from the industrialized countries of the global North. A striking example is Mexico’s imports of maize from the United States: since the North American Free Trade Agreement (NAFTA) went into effect a decade ago, imports have risen from one million metric tons/year to more than six million, a volume equivalent to roughly one-quarter of Mexico's annual consumption (Audley et al., 2004, p. 22). These imports, coupled with the Mexican government's withdrawal of price supports for maize farmers, have caused real producer prices to plummet by 70\% (OXFAM, 2003, p. 2).

The competitive edge that permits US corn to capture Mexican markets has several sources. Genuine comparative advantage is part of the story: the regular rainfall, fertile soils, and harsh winters that suppress pest populations help to make the midwestern US 'corn belt' a good place to grow maize. The broad array of agricultural support policies and subsidies in the US also make a contribution. ${ }^{22}$ The failure of market prices to internalize environmental costs ('negative externalities') confers a further advantage to US agriculture; the supply price of US maize does not include, for example, the social costs of widespread contamination of groundwater and surface waters by the herbicide atrazine. ${ }^{23}$ Last, but not least, the failure of market prices to internalize the environmental benefits of in situ conservation of crop genetic diversity (a 'positive externality') hobbles the competitive position of small-scale Mexican farmers.

International trade thus allows low-diversity agriculture in the North to displace high-diversity agriculture in the South. Trade reform efforts - for example, efforts to curtail US and European Union policies that foster overproduction and the dumping of agricultural products on world markets - would help to level the playing field for small farmers. But as long as externalities are left out of the picture, systematic biases against small farmers will persist. For small farmers in the global South, and above all in the centers of diversity, policies to reward the environmental service of in situ conservation are of key importance. In effect, these small farmers subsidize modern agriculture and food consumers worldwide. The way to end this subsidy is not to eliminate the environmental service by driving small farmers off the land, but instead to reward their contributions to world food security.

\section{What is to be Done?}

A wide range of policies can be envisioned that would reward small farmers for sustaining agricultural biodiversity. Such policies would both strengthen rural livelihood security and provide incentives for continued in situ conservation. In other words, rather than posing a tradeoff between poverty reduction and environmental protection, these are policies that would advance both goals simultaneously. ${ }^{24}$

(i) Removal of anti-small farmer policy distortions: As noted above, the competitive advantage of large farmers and low-diversity agriculture rests, in part, on government 
policies that favor capital-intensive agricultural technologies and promote the dumping of surplus agricultural products on world markets. While the removal of these distortions would not eliminate other biases that arise from neglect of externalities, this would be a step in the right direction.

(ii) Social recognition: Another important step would be to promote 'non-economic' rewards for the conservation of agricultural biodiversity. At the annual 'feria del elote' (corn fair) in Jala, Mexico, for example, farmers get prizes for producing the finest examples of the valley's traditional landrace maize. Such recognition not only makes farmers feel good; it also helps to create public awareness of the need for policies to provide economic rewards.

(iii) Market development: 'A rose is a rose is a rose,' wrote the poet Gertrude Stein. However that may be (and rose lovers no doubt would have something to say about this), one ear of corn is not the same as any other. Traditional varieties of grains, vegetables, and fruits not only have different genetic attributes than modern varieties; they also look different, and most importantly, taste different. In part for this reason - and in part, by virtue of commitments to environmental values - there is scope for development of domestic and international markets in which traditional varieties command a price premium. Labeling systems, like the denominations of origin established for French wines in 1935, can assist in creating such markets (Mann, 2004). Again, this could not only provide direct rewards to growers, but also help to raise public consciousness of the importance of diversity and the need for public policies to sustain it. ${ }^{25}$

(iv) Provision of local public goods: Outmigration of small farmers is propelled in part by lack of local public goods, such as schools and health clinics. To encourage small farmers to remain on the land, and to provide tangible evidence of the value society places on the environmental services they provide, governments and international agencies could invest in local public goods. Even in the absence of concerns over the erosion of agricultural biodiversity, there are compelling equity and efficiency arguments for such investments. The need to conserve diversity merely adds to the case.

(v) Payments for environmental services: A further possibility that warrants serious exploration is payments to farmers who provide the environmental service of in situ conservation. For such payments to become a part of the policy mix, two main questions would need to be resolved: how to structure the payments, and how to finance them. Payments could take the form of a 'bonus' per unit output, (as suggested by Nadal, 2000, p. 104), or a payment per unit area under the crop, which would have the advantage of removing biases against varieties with low yields per unit area. In determining which individuals or communities should receive payments, there may be tradeoffs between precision and inclusivity, and a good case can be made for the latter. 'When money falls from heaven into a poor community,' Peter Rosset comments, 'it often ends up accentuating the power and wealth differences in the community,' and can 'even lead to violence. ${ }^{26}$ Structuring payments so as to strengthen rural communities will be a key challenge. ${ }^{27}$ With regard to sources of finance, the fact that the benefits of agricultural biodiversity are truly global means that local and national governments should not have 
to bear the entire cost of sustaining it. There is a need to mobilize international resources, perhaps under the aegis of the Global Environment Facility. ${ }^{28}$

(vi) Policies to encourage part-time farming: Finally, we should recognize that farming need not be an all-or-nothing occupational choice. In Japan, for example, only $15 \%$ of the country's three million farm households (a number that is down from six million in 1960) earn their livelihoods entirely from farming; three-quarters derive most of their income from non-farm sources (see Figure 3). Just as the adoption of 'modern' crop varieties does not necessarily eliminate 'traditional' varieties, so the expansion of non-farm employment does not necessarily eliminate farming. Policies that help to generate parttime, off-farm employment opportunities in rural areas can help to sustain small farms. So can policies that promote agriculture-friendly tourism, thereby internalizing another positive externality often generated by small-farm landscapes: scenic beauty. ${ }^{29} \mathrm{In}$ supporting small farms, such policies could help to sustain agricultural biodiversity, especially if accompanied by other policies that recognize and reward the social value of in situ conservation.

Figure 3: Distribution of Farm Households in Japan, 2002

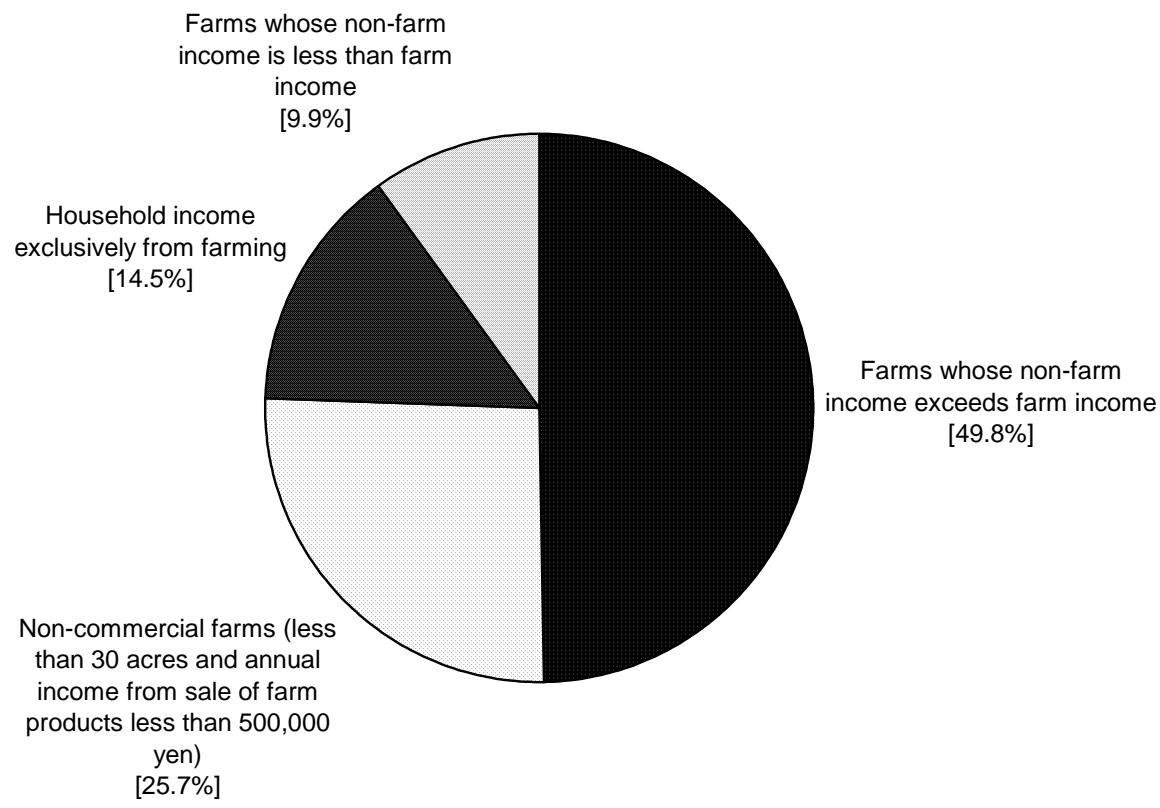

Source: Government of Japan (2003, p. 57). 
These policies are not mutually exclusive, nor is any one policy alone likely to be sufficient. Taken together, however, these policies could do a great deal to support small farms and stewardship of agricultural biodiversity.

\section{Conclusion}

There is a future for small farms. Or, to be more precise, there can be and should be a future for them. Given the dependence of 'modern' low-diversity agriculture on 'traditional' high-diversity agriculture, the long-term food security of humankind will depend on small farms and their continued provision of the environmental service of in situ conservation of crop genetic diversity. Policies to support small farms can be advocated, therefore, not merely as a matter of sympathy, or nostalgia, or equity. Such policies are also a matter of human survival.

The diversity that underpins the sustainability of world agriculture did not fall from the sky. It was bequeathed to us by the 400 generations of farmers who have carried on the process of artificial selection since plants were first domesticated. Until recently, we took this diversity for granted. The ancient reservoirs of crop genetic diversity, plant geneticist Jack Harlan (1975, p. 619) wrote three decades ago, 'seemed to most people as inexhaustible as oil in Arabia.' Yet, Harlan warned, 'the speed which enormous crop diversity can be essentially wiped out is astonishing.'

The central thesis of this essay is that efforts to conserve in situ diversity must go hand-in-hand with efforts to support the small farmers around the world who sustain this diversity. Economists and environmentalists alike by and large have neglected this issue. In thrall to a myopic notion of efficiency, many economists fail to appreciate that diversity is the sine qua non of resilience and sustainability. In thrall to a romantic notion of 'wilderness,' many environmentalists fail to appreciate that agricultural biodiversity is just as valuable - indeed, arguably more valuable from the standpoint of human well-being - as the diversity found in tropical rainforests or the spotted owls found in the ancient forests of the northwestern United States.

Today a formidable nexus of market forces and political forces threatens both small farmers and the agricultural biodiversity they sustain. Several countervailing public policies have been suggested here: removal of policy biases against small farmers; social recognition of the contribution of in situ conservation to human well-being; development of markets for 'traditional' varieties; provision of local public goods in areas where farmers cultivate diversity; payments for the environmental service of on-farm conservation; and policies to support parttime farming as a component of household livelihood strategies.

Only an awakened and mobilized public opinion can bring such policies into being. Small farmers cannot do it alone: they need allies. A process of 'artificial selection' is needed in the policy arena to yield outcomes that will not come about from 'natural selection' by market forces and the political influence of the powerful. No less than farming itself, ensuring a sustainable future requires human intelligence and human agency. In the present era of globalization, all of us share responsibility for the cultivation of agricultural biodiversity. 


\section{Notes}

1 ‘A French Roadblock to Free Trade,’ The New York Times, 3 August 2003.

${ }^{2}$ Personal interview, Guatemala City, December 1997.

${ }^{3}$ For the incorporation of this recognition into recent thinking at the World Bank, see Deininger (2003).

4 The term 'agricultural biodiversity' is often used to refer not only to crop genetic diversity, but also other related forms of biodiversity, including pathogens, insects, and soil microorganisms (see, for example, Wood and Lenné, 1999). Here my focus is crop genetic diversity, and I will use the terms interchangeably; much of the discussion could be generalized, however, to other forms of agricultural biodiversity.

${ }^{5}$ Wilkes (1995, p. 207) suggests that we call this process 'anthro-selection,' in recognition of the human-centered nature of the process.

${ }^{6}$ See Mann (2002a). See also Brookfield (2001, pp. 96-97) for discussion of this and other examples of 'manufactured soils.'

${ }^{7}$ For discussions of the origins of these and other crop plants, see MacNeish (1992), Harlan (1995), Smartt and Simmonds (1995), and Smith (1995).

${ }^{8}$ For further discussion of the contrasts between Mexican and US maize agriculture, see Boyce (1996).

${ }^{9}$ For discussion of differences in the 'real cost' of family labor versus hired labor, see Sen (1975). For discussion farm size and labor supervision, see Boyce (1987, pp. 39-40, 213).

${ }^{10}$ Nadal (2000, p. 122), citing Ortega Paczka (1997). Women often play a particularly important role in agricultural biodiversity conservation; for example, surveys in indigenous communities in the Guatemalan highlands have found that women often select the seed for the next production cycle, doing so on the basis of culinary requirements and Mayan cosmology as well as agronomic characteristics (FAO/IPGRI, 2002, pp. 22, 39-40).

11 The term 'evolutionary gardens' is used by Wilkes (1992, pp. 24-26) to describe the hilly, rainfed milpa plots cultivated by the campesinos of Mesoamerica.

12 Most plant breeding is still performed in the public sector, notwithstanding the growing importance of private-sector breeders and the publicity that has accompanied this trend.

${ }^{13}$ See Brammer (1980) and Biggs (1980). See also Bellon, Pham, and Jackson (1997).

${ }^{14}$ Quoted by Fowler and Mooney (1990, p. xii). 
${ }^{15}$ In the late 1960s, for example, CIMMYT sent 'back-up copies' of about 5000 varieties of Latin American maize to the NSSL in Fort Collins. When CIMMYT asked for some of these back, having lost some of its own samples in a period of budgetary shortfalls, it turned out that most of the seeds sent to the NSSL had been inadvertently discarded (Raeburn, 1995, pp. 62-3). See also Brookfield (2001, p. 247), who concludes that 'a high proportion of the world's seed storage has substandard conditions, and there is concern about the viability of many collections.'

${ }^{16}$ Personal communication, May 2004.

${ }^{17}$ Personal interview with Joel Charny, who retrieved the seed samples from IRRI while working for OXFAM-America in the 1980s.

${ }^{18}$ For examples of genetic erosion associated with this outmigration, see Nadal (2000, pp. 9091).

${ }^{19}$ For further discussion, see also Griffin (1979; 1999, ch. 6) and Boyce (1993, chs. 3-5).

${ }^{20}$ For examples in the case of potato cultivation in the Andes, see Ochoa (1975).

${ }^{21}$ For discussion, see Qualset et al. (1997), Wood and Lenné (1997), Edwards et al. (1999) and Jana (1999).

${ }^{22}$ For discussion, see Wise (2004).

${ }^{23}$ See Boyce (1996) and Ackerman (2002).

24 The policies sketched here are examples of the 'internalization' route to building natural assets in the hands of the poor (Boyce, 2003). For further discussion, see 'Crop Genetic Diversity and Rural Livelihoods,' the minutes of a June 2001 meeting organized by the Political Economy Research Institute in San Cristóbal de las Casas, Chiapas (available at Hhttp://www.umass.edu/peri/pdfs/CGDMinutes.pdfH). See also Thrupp (1998) and Brush (2000).

${ }^{25}$ For examples from Switzerland, see Bardsley and Thomas (2004). For discussion, see also Smale et al. (2004, pp. 130-1).

${ }^{26}$ Quoted by Mann (2004, p. 23).

${ }^{27}$ In Guatemala's western highlands, for example, small farmers who cultivate traditional maize varieties also invest in labor-intensive land improvements such as terracing and the cultivation of live barriers to control soil erosion, despite lack of formal land titles. Elizabeth Katz (2000, p. 124) attributes their willingness to undertake these investments to 'informal social recognition of property rights - a manifestation of social capital - at the community level, which effectively replaces formal legal title.' If payments for environmental services were to erode this social 
capital, the net effect paradoxically could be to undermine such investments. See also Rosa et al. (2004).

${ }^{28}$ The Global Environment Facility (GEF) has begun to contemplate work in this area; see GEF (2000).

${ }^{29}$ In some cases, agricultural biodiversity itself has tourism value. For example, in Cusco, Peru, tour groups can visit a potato museum, demonstration plots, and restaurants featuring traditional produce (Cromwell et al., 1999, p. 35). 


\section{References}

Ackerman, Frank (2002) 'Is the United States a Pollution Haven?' Silver City, NM: Interhemispheric Resource Center. Available at: http://www.fpif.org/americas/commentary/2002/0203corn.html.

Ackerman, Frank et al. (2003) 'Free Trade, Corn, and the Environment: Environmental Impacts of US - Mexico Corn Trade Under NAFTA,’ Medford, MA: Tufts University, Global Development and Environment Institute, Working Paper No. 03-06. Available at: http://ase.tufts.edu/gdae/Pubs/wp/03-06-NAFTACorn.PDF.

Audley, John J. et al. (2004) NAFTA’s Promise and Reality: Lessons from Mexico for the Hemisphere. Washington, DC: Carnegie Endowment for International Peace.

Bardsley D. and I. Thomas I. (2004) 'In Situ Agrobiodiversity Conservation in the Swiss Inner Alpine Zone, ’GeoJournal 60( 2): 99-109.

Bellon, M.R., J.-L. Pham, and M.T. Jackson (1997) 'Genetic Conservation: A Role for Rice Farmers,' in N. Maxted, B. Ford-Lloyd, and J.G. Hawkes, eds., Plant Genetic Conservation: The In Situ Approach. London: Chapman \& Hall, pp. 263-289.

Biggs, Stephen D. (1980) 'Informal R\&D,' Ceres (Rome: Food and Agriculture Organization) 13(4): 23-26.

Boyce, James K. (2003) 'From Natural Resources to Natural Assets,' in James K. Boyce and Barry G. Shelley, eds., Natural Assets: Democratizing Environmental Ownership. Washington, DC: Island Press, pp. 7-28.

Boyce, James K. (1996) 'Ecological Distribution, Agricultural Trade Liberalization, and in situ Genetic Diversity,’ Journal of Income Distribution 6(2), 263-284.

Boyce, James K. (1993) The Philippines: The Political Economy of Growth and Impoverishment in the Marcos Era. London: Macmillan.

Boyce, James K. (1987) Agrarian Impasse in Bengal: Institutional Constraints to Technological Change. Oxford: Oxford University Press.

Brammer, Hugh (1980) 'Some Innovations Don’t Wait for Experts,' Ceres (Rome: Food and Agriculture Organization) 13(2): 24-28.

Brookfield, Harold (2001) Exploring Agrodiversity. New York: Columbia University Press.

Brush, Stephen B., ed. (2000) Genes in the Field: On-Farm Conservation of Crop Diversity. Rome: International Plant Genetic Resources Institute. 
Brush, Stephen B. (1995) 'In Situ Conservation of Landraces in Centers of Crop Diversity,’ Crop Science 35: 346-354.

Chang, T. T. (1995) 'Rice,’ in Smartt and Simmonds, eds., pp. 147-155.

Cromwell, Elizabeth, David Cooper, and Patrick Mulvany (1999) 'Agriculture, Biodiversity and Livelihoods: Issues and Entry Points for Development Agencies,' London: Overseas Development Institute. Available at: http://www.ukabc.org/odi_agbiod.pdf.

Darwin, Charles (1952 [1859]) The Origin of Species by Means of Natural Selection. Chicago: Encyclopaedia Britannica.

Deininger, Klaus (2003) Land Policies for Growth and Poverty Reduction. Oxford: Oxford University Press.

Duvick, Daniel N. (1984) 'Genetic Diversity in Major Farm Crops on the Farm and in Reserve,’ Economic Botany 38(2): 161-178.

Duvick, D.N., J.S.C. Smith, and M. Cooper (2004) 'Changes in Performance, Parentage, and Genetic Diversity of Successful Corn Hybrids, from 1930 to 2000,' in C.W. Smith, J. Betrán, and E. C. A. Runge, eds., Corn: Origin, History, Technology, and Production. New York: John Wiley \& Sons.

Edwards, P.J., J. Kollmann, and D. Wood (1999) 'Determinants of Agrobiodiversity in the Agricultural Landscape,’ in Wood and Lenné, eds., pp. 183-210.

Food and Agriculture Organization of the United Nations (FAO) and International Plant Genetic Resources Institute (IPGRI) (2002) The Role of Women in the Conservation of the Genetic Resources of Maize. Rome: FAO/IPGRI.

Fowler, Cary and Pat Mooney (1990) Shattering: Food, Politics, and the Loss of Genetic Diversity. Tucson: University of Arizona Press.

García-Barrios, Raúl and Luis (1990) 'Environmental and Technological Degradation in Peasant Agriculture: A Consequence of Development in Mexico,' World Development 18(11): 1569-85.

Global Environment Facility (2000) 'Elements of a GEF Operational Program on Conservation and Sustainable Use of Biological Diversity Important to Agriculture,’ 12 April. Available at: http://www.gefweb.org/COUNCIL/GEF_C15/GEF_C15_7.pdf.

Goodman, Major M. (1995) ‘Maize’’ in Smartt and Simmonds, pp. 193-202.

Government of Japan (2003) Statistical Handbook of Japan, 2003. Tokyo: Ministry of Public Management, Home Affairs, Post and Telecommunications, Statistics Bureau. 
Griffin, Keith (1999) Alternative Strategies for Economic Development. Second edn. London: Macmillan.

Griffin, Keith (1979) The Political Economy of Agrarian Change. Second edn. London: Macmillan.

Griffin, Keith, Azizur Rahman Khan, and Amy Ickowitz (2002) 'Poverty and the Distribution of Land,’ Journal of Agrarian Change 2(3): 279-330.

Harlan, Jack R. (1995) The Living Fields: Our Agricultural Heritage. Cambridge: Cambridge University Press.

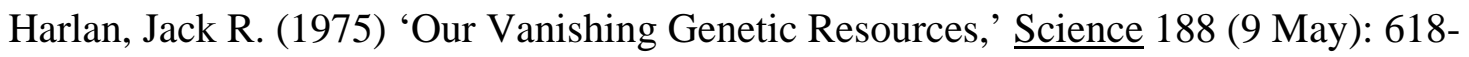
621.

Heywood, V.H. (1995) Global Biodiversity Assessment. Cambridge: Cambridge University Press.

Jana, S. (1999) 'Some Recent Issues on the Conservation of Crop Genetic Resources in Developing Countries,’ Genome 42: 562-569.

Katz, Elizabeth (2000) 'Social Capital and Natural Capital: A Comparative Analysis of Land Tenure and Natural Resource Management in Guatemala,' Land Economics 76(1): 114-132.

Lewis, W. Arthur (1954) 'Economic Development with Unlimited Supplies of Labor,' The Manchester School of Economic and Social Studies 22: 139-191.

MacNeish, Richard S. (1992) The Origins of Agriculture and Settled Life. Norman: University of Oklahoma Press.

Mann, Charles (2004) Diversity on the Farm. New York: Ford Foundation; and Amherst, MA: Political Economy Research Institute.

Mann, Charles (2002a) 'The Real Dirt on Rainforest Fertility,' Science 297: 920-923.

Mann, Charles (2002b) ‘1491,’ Atlantic Monthly, March: 41-53.

Nadal, Alejandro (2000) 'The Environmental and Social Impacts of Economic Liberalization on Corn Production in Mexico,' Oxford: Oxfam, and Gland: WWF International. Available at: http://www.oxfam.org.uk/what_we_do/issues/livelihoods/corn_mexico.htm. 
Ochoa, Carlos (1975) 'Potato Collecting Expeditions in Chile, Bolivia and Peru, and the Genetic Erosion of Indigenous Cultivars,' in O.H. Frankel and J.G. Hawkes, eds., Crop Genetic Resources for Today and Tomorrow. Cambridge: Cambridge University Press.

Ortega Paczka, Rafael A. (1997) 'Maíz en el Tratado de Libre Comercio: Implicaciones para el medio ambiente. Recursos genéticos.' Consultant's report to the Commission on Environmental Cooperation.

OXFAM (2003) 'Dumping Without Borders: How US agricultural policies are destroying the livelihoods of Mexican corn farmers,' Oxford: OXFAM Briefing Paper No. 50, August. Available at: http://www.oxfam.org/eng/pdfs/pp030827_corn_dumping.pdf.

Peña, Devon (2003) 'The Watershed Commonwealth of the Upper Rio Grande,' in James K. Boyce and Barry G. Shelley, eds., Natural Assets: Democratizing Environmental Ownership. Washington, D.C.: Island Press.

Plucknett, D. L. et al. (1987) Gene Banks and the World’s Food. Princeton: Princeton University Press.

Qualset, C.O., A.B. Damania, A.C.A. Zanatta, and S.B. Brush (1997) 'Locally Based Crop Plant Conservation,’ in N. Maxted, B. Ford-Lloyd, and J.G. Hawkes, eds., Plant Genetic Conservation: The In Situ Approach. London: Chapman \& Hall, pp. 160-175.

Raeburn, Paul (1995) The Last Harvest. New York: Simon \& Schuster.

Rosa, Herman, Deborah Barry, Susan Kandel, and Leopoldo Dimas (2004) 'Compensation for Environmental Services and Rural Communities: Lessons from the Americas,' in James K. Boyce and Sunita Narain, eds., Reclaiming Nature: Worldwide Strategies for Building Natural Assets to Fight Poverty (forthcoming).

Sen, Amartya (1975) Employment, Technology, and Development. Oxford: Oxford University Press.

Shand, Hope (1997) Human Nature: Agricultural Biodiversity and Farm-based Food Security. Ottawa: Rural Advancement Foundation International. Available at: http://www.etcgroup.org/documents/other_human.pdf.

Smale, Melinda, Mauricio R. Bellon, Devra Jarvis, and Bhuwon Sthapit (2004) 'Economic Concepts for Designing Policies to Conserve Crop Genetic Resources on Farms,' Genetic Resources and Crop Evolution 51: 121-135.

Smartt, J. and Simmonds, N.W., eds. (1995) Evolution of Crop Plants. $2^{\text {nd }}$ edn. Harlow: Longman Scientific \& Technical.

Smith, Bruce D. (1995) The Emergence of Agriculture. New York: Scientific American Library. 
Stam, Jerome M. and Bruce L. Dixon (2004) 'Farmer Bankruptcies and Farm Exits in the United States, 1899-2002,’ Washington, D.C.: U.S. Department of Agriculture, Economic Research Service, Agriculture Information Bulletin No. 788. Available at: http://www.ers.usda.gov/publications/aib788/aib788.pdf.

Swanson, T.M. and R.A. Luxmoore (1997) 'Industrial Reliance on Biodiversity,' Cambridge, U.K.: World Conservation Monitoring Centre, Biodiversity Series No. 7. Available at: http://www.eldis.org/static/DOC6611.htm.

Thrupp, Lori Ann (1998) Cultivating Diversity: Agrobiodiversity and Food Security. Washington, DC: World Resources Institute.

Vavilov, Nikolai I. (1992 [1926]) Origin and Geography of Cultivated Plants. Cambridge: Cambridge University Press.

Wilkes, Garrison (1992) Strategies for Sustaining Crop Germplasm Preservation, Enhancement, and Use. Consultative Group on International Agricultural Research, Washington, D.C.

Wilkes, Garrison (1995) 'The Ethnobotany of Artificial Selection in Seed Plant Domestication,' in Richard E. Schultes and Siri von Reis, eds., Ethnobotany: Evolution of a Discipline. Portland, OR: Dioscorides Press, pp. 203-208.

Wise, Timothy A. (2004) 'The Paradox of Agricultural Subsidies: Measurement Issues, Agricultural Dumping, and Policy Reform,’ Medford, MA: Tufts University, Global Development and Environment Institute, Working Paper No. 04-02. Available at: http://ase.tufts.edu/gdae/Pubs/wp/04-02AgSubsidies.pdf.

Wood, David and Jillian M. Lenné (1997) 'The Conservation of Agrobiodiversity OnFarm: Questioning the Emerging Paradigm,’ Biodiversity and Conservation 6: 109-129.

Wood, David and Jillian M. Lenné (1999) Agrobiodiversity: Characterization, Utilization and Management. Wallingford (U.K.): CABI Publishing. 